\title{
The Temperature Measurement Using LM35 on Shaking Water Bath
}

\author{
Wisnu Kartika ${ }^{1, *}$ Sumardi $^{1,}$ Nur Hudha Wijaya ${ }^{1}$ \\ ${ }^{1}$ Department of Medical Electronics Technology, Vocational Program, Universitas Muhammadiyah Yogyakarta \\ *Corresponding author. Email: wisnu2007@umy.ac.id
}

\begin{abstract}
On this era, there are several medical equipment especially on the medical laboratory. One of the equipment is Shaking Water Bath. The Shaking Water Bath is a module used for heating or incubating sample solutions and mixing. The previous Shaking Water Bath still has a manual drainage system, so you must turn the device over to remove and change the water and there is a possibility that we will be hurt to hot water. Therefore, a Shaking Water Bath module is designed which can fill and drain water automatically. The Shaking Water Bath module using LM35 sensor to detect the temperature of the water inside the chamber. The temperature measurement will be displayed on 4x20 character LCD. The testing taken by 20 times data collection. The testing results is the error value is $0.38 \%$ at 37 Celsius degree from 20 times data collection. From the research, the proposed scheme is work well and suitable for use.
\end{abstract}

Keywords-LM35, medical equipment, temperature

\section{INTRODUCTION}

On this era, the medical equipment is developed increasingly. The medical equipment is using modern component [1][2][3]. The main component of electronics devices is resistor, capacitor, and inductor. This component will be connected with diode and transistor to make a better device [4][5].

Now, several simple devices using a microcontroller to control the systems. The microcontroller can be connected to many sensor [6][7][8]. On this proposed scheme, the microcontroller is connected to the temperature sensor LM35 sensor [9][10][11].

On the medical equipment, like a Shaking Water Bath used to heating and incubating the solution sample is developed [12][13][14][15][16].

From the sample is heated by heater at 30 Celsius degree to 80 Celsius degree. From the previous research, we proposed a new scheme that is the Shaking Water Bath with temperature sensor and automatically water drainage.

\section{SYSTEM DESIGN}

The Figure 1 shows the power supply is connected to the microcontroller and all of the driver circuit. There are several push button to control the temperature, timer and motor. The microcontroller will be connected to the LM35 temperature sensor, motor, and heater. The measurement will be displayed on the LCD character. The heater is used to heat the water inside the chamber. The motor is used to shake the sample. If the sample process is completed so the buzzer will turn on.

The Figure 2 shows the block diagram of the module works. The module contains the microcontroller, the power supply unit, the driver, the motor, the LM35 temperature sensor, the buzzer and the heater. The working principle will be explained on this section. When the power button is turned on, so the supply will connect to the power supply and the heater.

The power supply on the module connects to the all of the circuit. The motor is used to shake the sample solution and the temperature control setup the temperature inside the chamber. The temperature measurement will be displayed on the LCD screen. The schematic diagram will be showed in this section. 


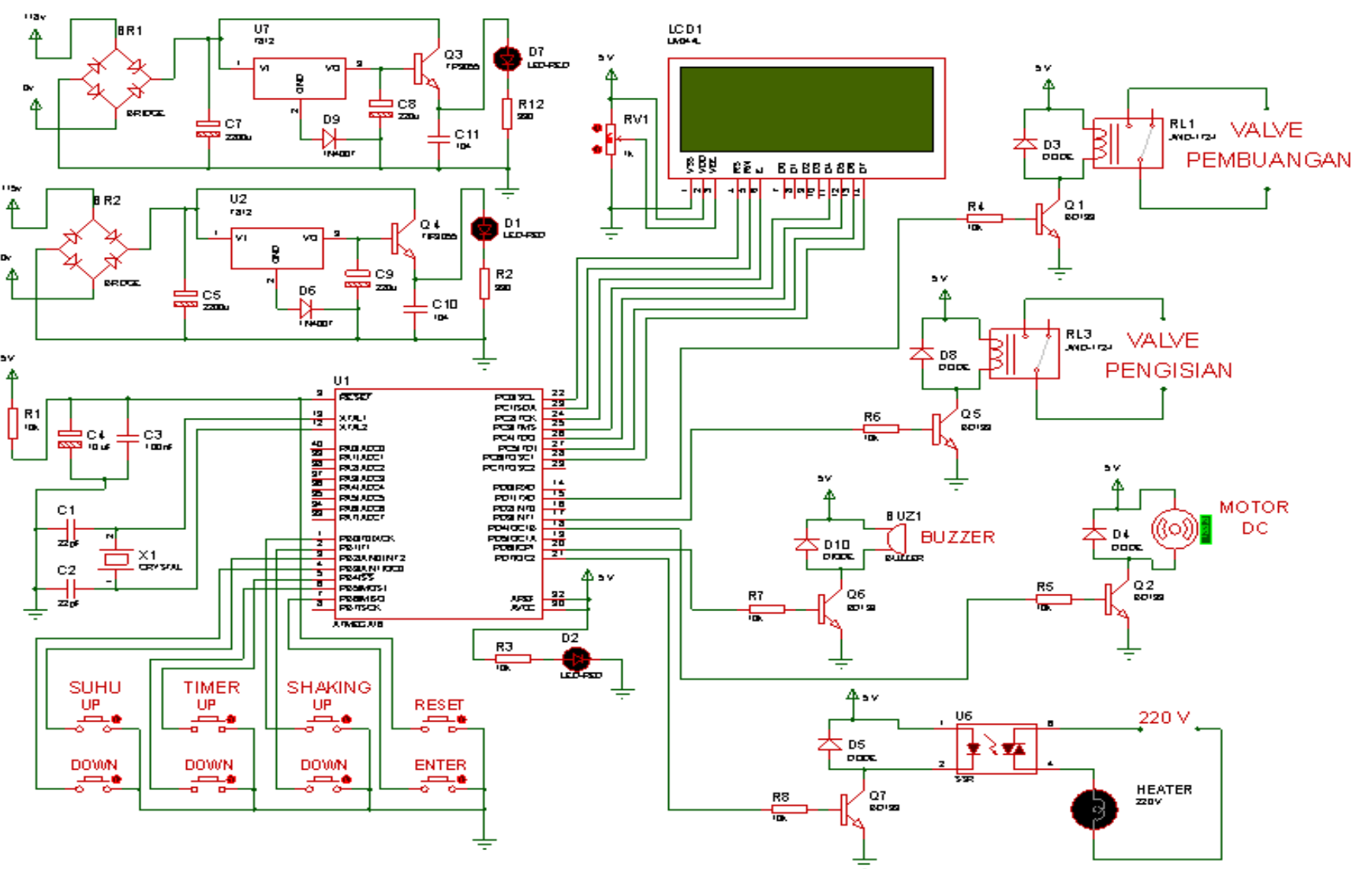

Figure 1. The Schematic Diagram

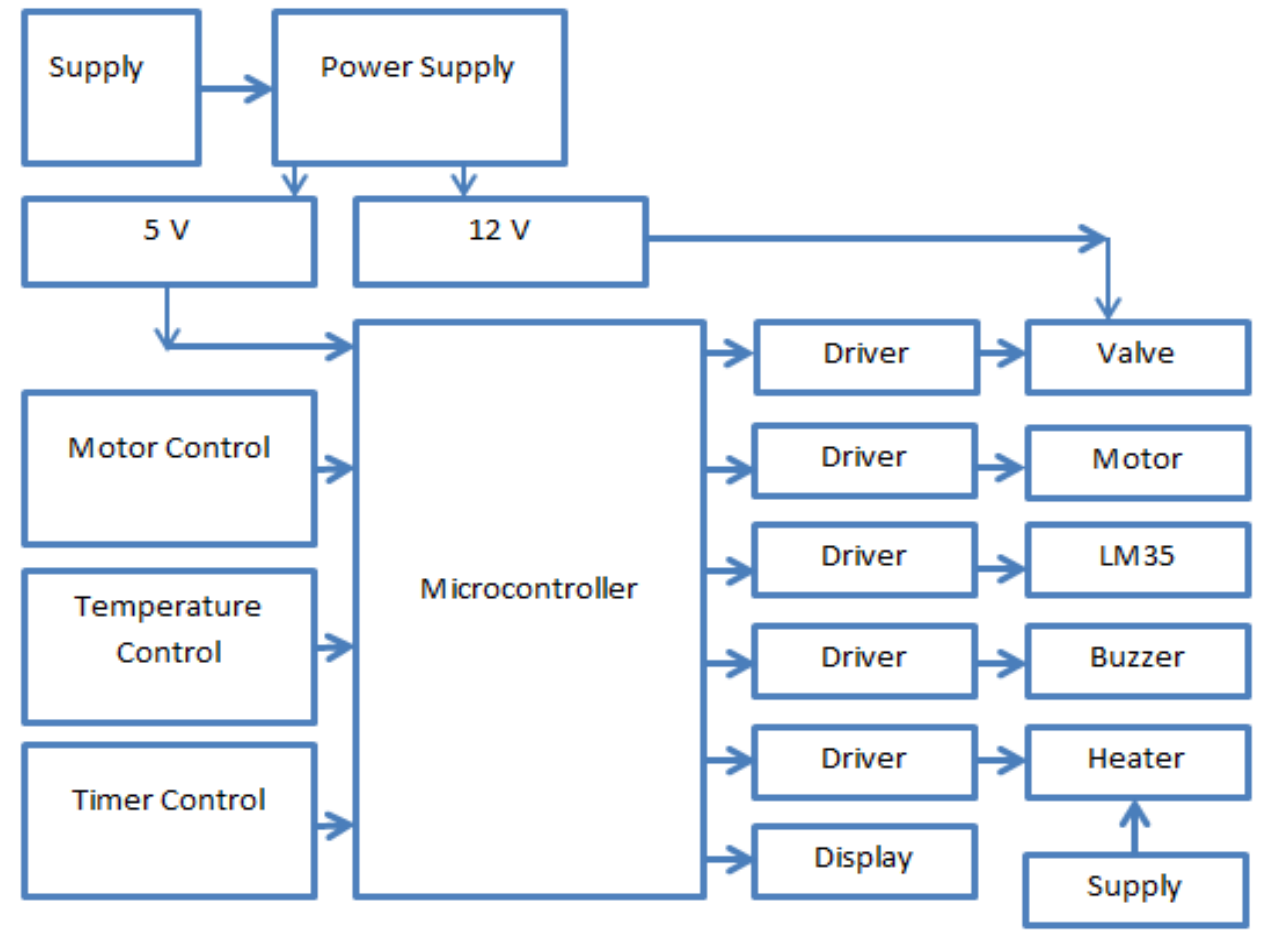

Figure 2. The Block Diagram 
The Figure 3 shows the power supply unit which connect to the entire circuit inside the module.

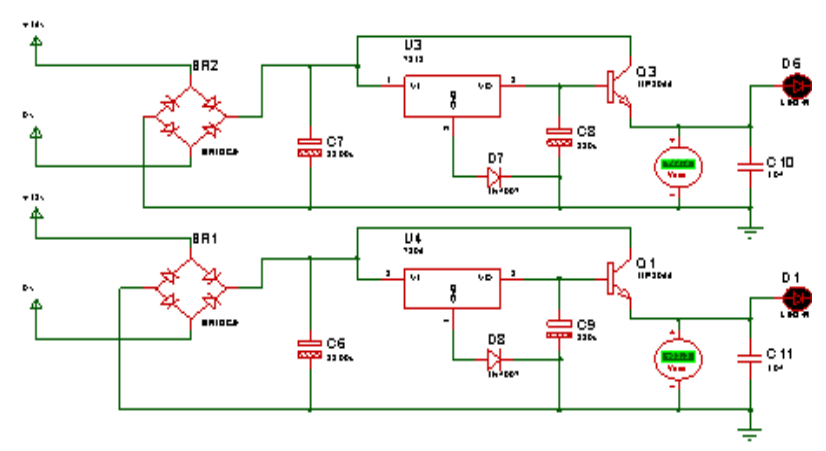

Figure 3. The Power Supply Unit

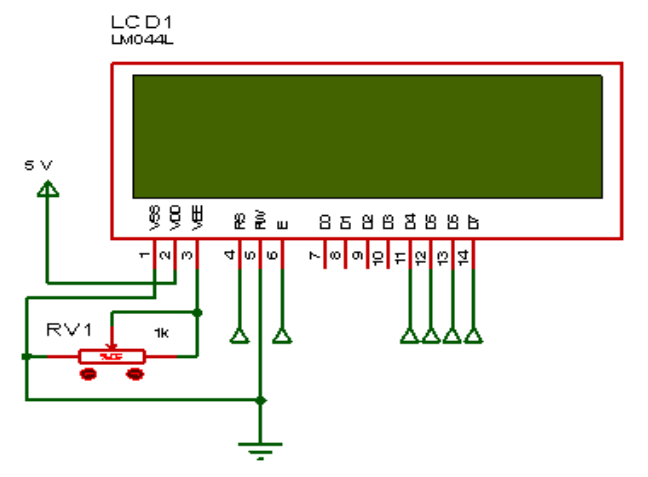

Figure 4 The LCD Circuit Unit

The Figure 4 shows the LCD unit which show the measurement temperature of the chamber.

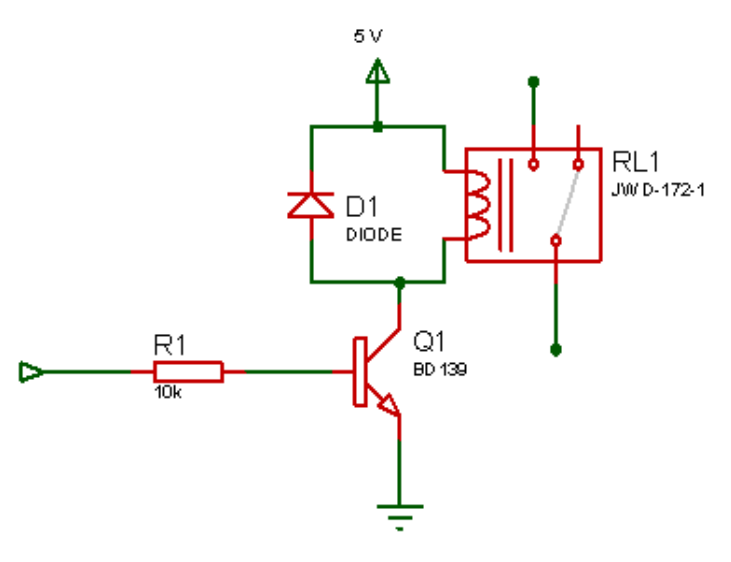

Figure 5. The Driver Valve Circuit

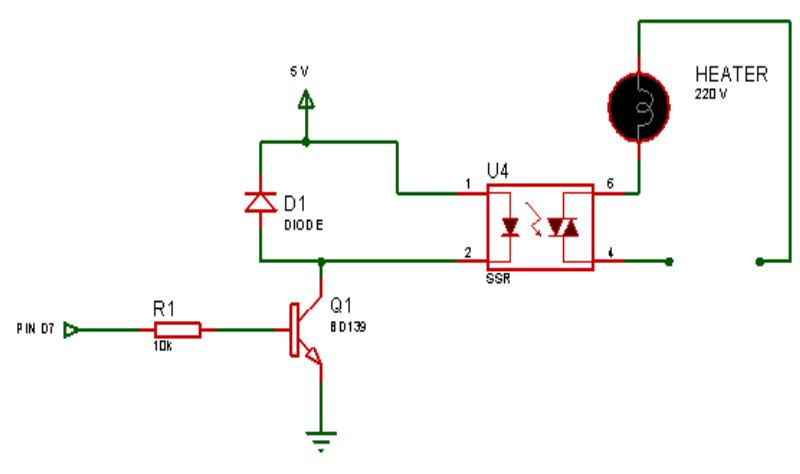

Figure 6. The Driver Heater Circuit

The Figure 6 shows the driver heater which can heating the chamber.

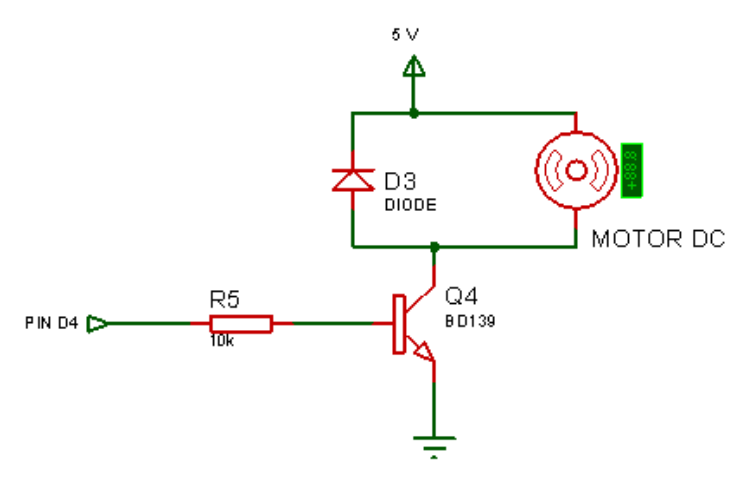

Figure 7 The Driver Motor Circuit

The Figure 7 shows the motor circuit which shake the solution from the right to the left and the left to the right.

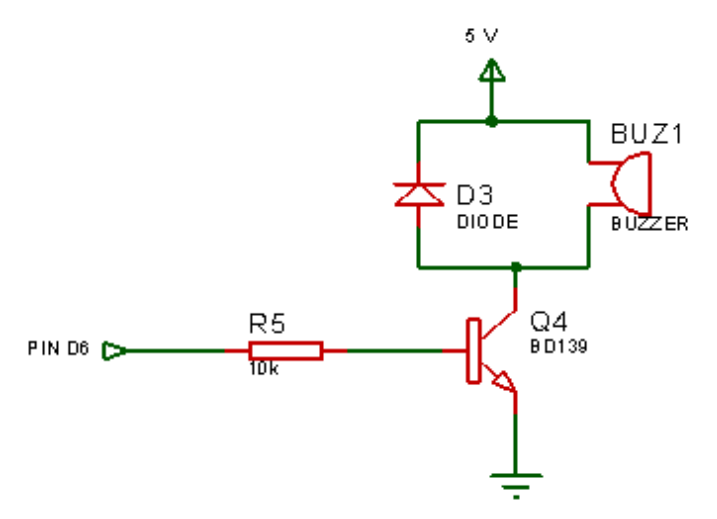

Figure 8. The Driver Buzzer Circuit

The Figure 8 is driver buzzer circuit. The buzzer will turn on when the operating of the system finish. 
The Figure 9 shows the proposed scheme module. The module contains the motor, the LM35 temperature sensor and another circuit. This module using microcontroller

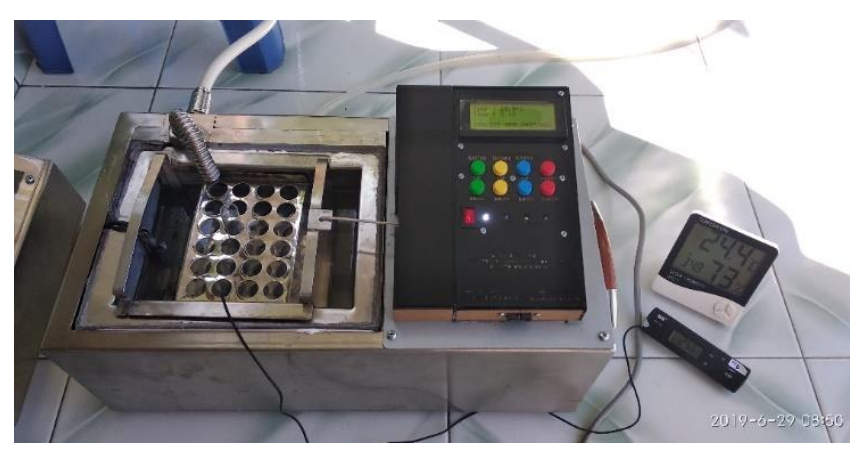

Figure 9. The Module

\section{THE RESULTS AND DISCUSSION}

In this section, it will be explained the testing of the module. The module will be testing 20 times.

Table 1 The Temperature Measurement on The Module

\begin{tabular}{|c|c|c|c|}
\hline No & $\begin{array}{c}\text { The } \\
\text { Module }\end{array}$ & $\begin{array}{c}\text { The } \\
\text { Thermometer }\end{array}$ & Error \\
\hline 1 & $37.1^{\circ} \mathrm{C}$ & $37.2^{\circ} \mathrm{C}$ & $0.1^{\circ} \mathrm{C}$ \\
\hline 2 & $37.1^{\circ} \mathrm{C}$ & $37.2^{\circ} \mathrm{C}$ & $0.1^{\circ} \mathrm{C}$ \\
\hline 3 & $37.6^{\circ} \mathrm{C}$ & $37.4^{\circ} \mathrm{C}$ & $0.2^{\circ} \mathrm{C}$ \\
\hline 4 & $37.6^{\circ} \mathrm{C}$ & $37.4^{\circ} \mathrm{C}$ & $0.2^{\circ} \mathrm{C}$ \\
\hline 5 & $37.1^{\circ} \mathrm{C}$ & $37.2^{\circ} \mathrm{C}$ & $0.1^{\circ} \mathrm{C}$ \\
\hline 6 & $37.1^{\circ} \mathrm{C}$ & $37.4^{\circ} \mathrm{C}$ & $0.3^{\circ} \mathrm{C}$ \\
\hline 7 & $37.1^{\circ} \mathrm{C}$ & $37.4^{\circ} \mathrm{C}$ & $0.3^{\circ} \mathrm{C}$ \\
\hline 8 & $37.1^{\circ} \mathrm{C}$ & $37.1^{\circ} \mathrm{C}$ & $0^{\circ} \mathrm{C}$ \\
\hline 9 & $37.1^{\circ} \mathrm{C}$ & $37.2^{\circ} \mathrm{C}$ & $0.1^{\circ} \mathrm{C}$ \\
\hline 10 & $37.1{ }^{\circ} \mathrm{C}$ & $37.4^{\circ} \mathrm{C}$ & $0.3^{\circ} \mathrm{C}$ \\
\hline 11 & $37.6^{\circ} \mathrm{C}$ & $37.6^{\circ} \mathrm{C}$ & $0^{\circ} \mathrm{C}$ \\
\hline 12 & $37.6^{\circ} \mathrm{C}$ & $37.4^{\circ} \mathrm{C}$ & $0.2^{\circ} \mathrm{C}$ \\
\hline 13 & $37.6^{\circ} \mathrm{C}$ & $37.8^{\circ} \mathrm{C}$ & $0.2^{\circ} \mathrm{C}$ \\
\hline 14 & $37.6^{\circ} \mathrm{C}$ & $37.2^{\circ} \mathrm{C}$ & $0.4^{\circ} \mathrm{C}$ \\
\hline 15 & $37.1^{\circ} \mathrm{C}$ & $37.6^{\circ} \mathrm{C}$ & $0.5^{\circ} \mathrm{C}$ \\
\hline 16 & $37.1^{\circ} \mathrm{C}$ & $37.4^{\circ} \mathrm{C}$ & $0.3^{\circ} \mathrm{C}$ \\
\hline 17 & $37.6^{\circ} \mathrm{C}$ & $37.7^{\circ} \mathrm{C}$ & $0.1^{\circ} \mathrm{C}$ \\
\hline 18 & $37.6^{\circ} \mathrm{C}$ & $37.6^{\circ} \mathrm{C}$ & $0^{\circ} \mathrm{C}$ \\
\hline 19 & $37.1^{\circ} \mathrm{C}$ & $37.2^{\circ} \mathrm{C}$ & $0.1^{\circ} \mathrm{C}$ \\
\hline 20 & $37.1^{\circ} \mathrm{C}$ & $37.4^{\circ} \mathrm{C}$ & $0.3^{\circ} \mathrm{C}$ \\
\hline \multicolumn{2}{|c|}{ Mean $\left({ }^{\circ} \mathrm{C}\right)$} & \multicolumn{2}{|l|}{$37.44^{\circ} \mathrm{C}$} \\
\hline \multicolumn{2}{|c|}{ Deviation } & \multicolumn{2}{|l|}{$0.34 \%$} \\
\hline \multicolumn{2}{|l|}{ Error } & \multicolumn{2}{|l|}{$0.92 \%$} \\
\hline
\end{tabular}

The measurement takes 20 times. The module shake the solution during 5 minutes. The module contain the water chamber and shaker. There are the LM35 temperature sensor to measure the temperature inside the chamber. The temperature measurement is displayed on the LCD screen.

The result of the temperature measurement is $37.4{ }^{\circ} \mathrm{C}$ as the average temperature and the error value is $0.92 \%$. The largest deviation at 14 th data $\left(0.6^{\circ} \mathrm{C}\right)$ and 15 th data $(0.5$ $\left.{ }^{\circ} \mathrm{C}\right)$. The deviation is on the tolerance limit that is below 1 ${ }^{\circ} \mathrm{C}$.

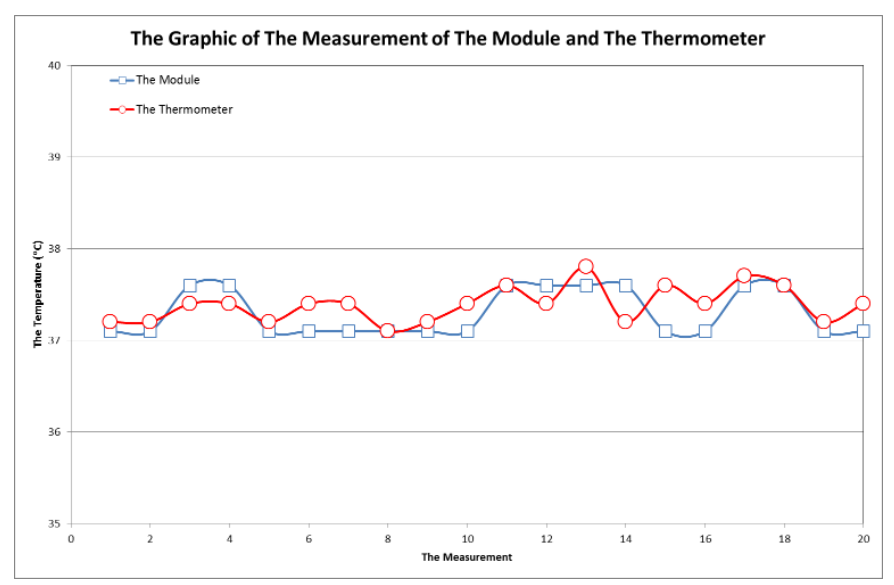

Figure 10. The Graphics from Table 1

\section{CONCLUSION}

From the research can be concluded that the proposed scheme module is work well. The module which is consisted the motor, the heater, the buzzer, the LM35 temperature sensor and the LCD character work well. The temperature measurement between modules if it is compared to the thermometer is on tolerance limit.

\section{AUTHORS' CONTRIBUTIONS}

There are two lecturer that is Wisnu Kartika and Nur Hudha Wijaya with a student named Sumardi.

\section{ACKNOWLEDGMENTS}

We say thankful to our team at Department of Medical Electronics Technology and all of the support.

\section{REFERENCES}

[1] E. Loniza, H. Habiburrahman, and S. Ariwibowo, "Prototype Injeksi Insulin Pump Dengan Control Panel Arduino Uno," Med. Tek. J. Tek. Elektromedik Indones., vol. 1, no. 2, pp. 1-5, 2020.

[2] H. R. Fajrin, R. N. Adnan, M. Irfan, and I. P. Sari, "Electronic Snellen Chart with Bluetooth Connection and Smartphone App," IOP Conf. Ser. Mater. Sci. Eng., vol. 851, p. 012018, 2020.

[3] R. Y. Endra, A. Cucus, and F. N. Affandi, "The 
Concept and Implementation of Smart Room using Internet of things (IoT) for Cost Efficiency and Room Security," J. Phys. Conf. Ser., vol. 1381, no. 1, 2019.

[4] M. Safitri, W. D. Iswara, and T. Harjono, "Blood Bag Shaker Dilengkapi Pemilihan Kecepatan Motor," Med. Tek. J. Tek. Elektromedik Indones., vol. 1, no. 2, 2020.

[5] Darmini, P. Ari Setiyono, D. Rochmayanti, A. Nino Kurniawan, and A. Nugroho Setiawan, "The Optimization of Mastoid CT Image Using Windows and Kernel Reconstructions," J. Phys. Conf. Ser., vol. 1471, p. 012015, Feb. 2020.

[6] H. R. Fajrin, U. Zakiyyah, and K. Supriyadi, "Alat Pengukur Ph Berbasis Arduino," Med. Tek. J. Tek. Elektromedik Indones., vol. 1, no. 2, 2020.

[7] Yuhefizar, A. Nasution, R. Putra, E. Asri, and D. Satria, "IoT: Heart Rate Monitoring Tool Using Android with Alert Messanger Telegram System," IOP Conf. Ser. Mater. Sci. Eng., vol. 846, no. 1, 2020.

[8] I. P. Sari and H. R. Fajrin, "Mobile augmented reality using cloud database for interactive museum guiding system,” J. Phys. Conf. Ser., vol. 1193, no. 1, 2019.

[9] Y. Mukhlis, E. Triawati, and V. Ernita, "Design System on Chip PreAmp Embedded on Electrocardiograph Based 0,35 CMOS Technology," J. Phys. Conf. Ser., vol. 1175, no. 1, pp. 0-9, 2019.

[10] D. S. Putra, M. A. Ihsan, A. D. Kuraesin, Mustakim, G. S. Achmad Daengs, and I. B. A. I. Iswara, "Electromyography (EMG) signal classification for wrist movement using naïve bayes classifier," J. Phys. Conf. Ser., vol. 1424, p. 012013, Dec. 2019.

[11] H. R. Fajrin, M. R. Ilahi, B. S. Handoko, and I. P. Sari, "Body temperature monitoring based on telemedicine," J. Phys. Conf. Ser., vol. 1381, no. 1, 2019.

[12] N. Yasmin Khairani Zakaria, H. Zaini, S. Siraj, M. Md Yunus, and H. Hashim, "Learning of Medicinal Herbs Using QR Codes," J. Phys. Conf. Ser., vol. 1424, p. 012049, Dec. 2019.

[13] Ismail, K. Hawari, S. Yondri, Firdaus, Yefriadi, and N. Harun, "The Detecting of Damage Conductor with Guided Image filter," IOP Conf. Ser. Mater. Sci. Eng., vol. 846, no. 1, 2020.

[14] G. Santoso, S. Hani, S. Kristiyana, and Y. A. Saputra, "Design Non-Invasive of Blood Sugar Detector Prototypes Using Cellular Technology GPS-Based," J. Phys. Conf. Ser., vol. 1381, no. 1, 2019.

[15] W. M. Nooriman, A. H. Abdullah, N. A. Rahim, and K. Kamarudin, "Development of wireless sensor network for Harumanis Mango orchard's temperature, humidity and soil moisture monitoring," ISCAIE 2018 - 2018 IEEE Symp. Comput. Appl. Ind. Electron., pp. 263-268, 2018.

[16] A. Miqdad, K. Kadir, and S. F. Ahmed, "Development of data acquisition system for temperature and humidity monitoring scheme," 2017 IEEE Int. Conf. Smart Instrumentation, Meas. Appl. ICSIMA 2017, vol. 2017-Novem, no. November, pp. 1-4, 2018. 